\title{
Patriotism of Ulama in the Coastal Areas of Java: Philosophy and Political Doctrines of K.H. Muchlas Tegal (1886-1964)
}

\author{
A. Zaini Bisri \\ Faculty of Social and Political Sciences, Diponegoro University Semarang, \\ Faculty of Social and Political Sciences, Pancasakti University, Tegal, Central Java
}

\begin{abstract}
The concept of patriotism, as a form of nationalist sentiment, has experienced a gradual expansion from its origins and historical development. Patriotism stems from loyalty to the family developing into a defense commitment to the tribe, city-state, and later the nation-state. Based on its expression and the way in which it is conveyed, there are various forms and types of patriotism. The debate arises among scholars when discussing the effects and consequences of patriotism which can be constructive or destructive. Patriotism can change its face into jingoism or chauvinism. In European history after the French Revolution, patriotism even took its form in the racial fervor that triggered the catastrophic Great War (World War I). Europe-colonized Muslim countries that adopted European nationalism and the spirit of PanIslamism rose to liberate their nations in the early 20th century by fighting patriotically against the colonialists. In Indonesia, the ulema played an important role in the struggle for independence by applying the Islamic theological doctrine of jihad fii sabilillah (fighting in the path of Allah). From a study of the political biography of K.H. Muchlas Tegal, leader of Pesantren Panggung, it is found that, in addition to the doctrine of jihad against nonbeliever invaders, the ulema also used religious-political philosophy and doctrine that gave birth to a distinctive expression of patriotism, namely the "guided patriotism", a concept of patriotism determined by the ideology of its political opponents, especially when opposing PKI (Indonesian Communist Party) and DI/TII (Darul Islam Rebellion).
\end{abstract}

Keywords: Patriotism, political resistance, nationalism, jihad, Indonesian politic.

\section{Introduction}

A political biography of a character will always be related to many political events in the spirit of his era. Through biographical research, a person's experience and identity can be explored. Biographies provide an alternative analysis of the workings of social groups, situations, and events, which serve as a frame of reference for historical research. This analysis can improve understanding of the nature of politics as defined by Lasswell, namely "who gets what, when, and how" [1]. Biographies not only describe the philosophy of life, thoughts, and actions of a character in responding to the dynamics of the environment around 
them but also how that character influences social change. In the view of Taufik Abdullah's historian, there are always controversies in the life of a character. However, apart from the assessment controversy, the activities of these figures will always give birth to meaning [2]. Although discussing the individual, the dimensions shown in the biography are for the crowd [3]. Therefore, a biography tells the story of the past, which is the basis for the present and binoculars to see the future.

In the scientific and intellectual traditions of Islam, the biographies of ulama are an important source for the understanding of Muslims towards their religious teachings. This tradition begins with the Sirah Nabawiyyah, the first and most important biography in Islamic historiography of the Prophet Muhammad by Ibn Ishaq (704-768), which was later edited by Ibn Hisham (d. 834). Sirah Nabawiyyah is the most comprehensive major work. From this main work were born other biographies of the Prophet Muhammad, thabaqat (biographical dictionary), manaqib (hagiography), tadzkirah (memoirs), and other forms of work. Most of the biographies of contemporary scholars are hagiographies which are usually written by students to commemorate the virtues and wonders of their teachers. However, recently there have been many biographies of ulama from research that refer to the critical historical method.

The political philosophy and doctrine of K.H. Muchlas Tegal was extracted from research on his life history that I did in 2004-2005, which was then continued in 2018-2019. Kiai Muchlas, who was born in 1886 and died in 1964, was a great ulama of his time in Tegal, an area on the north coast of West Central Java. As well as being a kiai who leads the Panggung Pesantren to transmit religious knowledge to his students and spread Islam in his area, Kiai Muchlas is also a freedom fighter and a Masyumi Party politician. He was chairman of the Majelis Syuro Masyumi Tegal in the 1950s. As a freedom fighter, he played a lot in motivating the spirit of the students and the Tegal community to fight against the Dutch colonialists. Through recitation and sermons on Friday, he awakened the awareness of Muslims in Tegal about the importance of the struggle to free Indonesia from colonialism. To the youths, he pumped their mentality and courage to compete on the battlefield.

During the physical revolution of 1945-1950, Kiai Muchlas's role was well known in strengthening the mentality of the fighters of Hizbullah, the militia group formed by Masyumi, by blessing bambu runcing (sharp bamboo) as the traditional weapon of the Hizbullah army. There are two ulama in Central Java who are known as prayer givers to provide supernatural powers to freedom fighters, namely Kiai Subeki at the Pesantren (Islamic Boarding School) Bambu Runcing Parakan (Temanggung) [4] and Kiai Muchlas in Tegal [5]. Apart from these two ulama, in Bekasi (West Java) K.H. Noer Alie is also known as a supernatural provider of supplies to freedom fighters [6]. With a prayer ritual guided by the two charismatic kiai, the Hizbullah fighters departed courageously for various battlefields against the Dutch who intended to regain control of Indonesia. They also relied on this spiritual asset when they joined the Republican troops against the Allied forces in the Battle of 10 November 1945 in Surabaya, which was later commemorated as Heroes' Day.

Knowing this role, the Dutch then targeted Kiai Muchlas. When the Dutch troops landed at Tegal Harbor during Military Aggression I, their huts and houses were hit by a cannon from the sea. The cottage and part of his house were burned down, but Kiai Muchlas and his family survived because they had already fled to Kediri. During the three years of refuge in Kediri, to be precise at the Pesantren Lirboyo, Kiai Muchlas's family was accommodated by his brotherin-law, K.H. Mahrus Aly who is one of the caretakers of the Pesantren Lirboyo. During the Guided Democracy period, Kiai Muchlas as Masyumi's figure and advisor in Tegal faced fierce political competition and ideological conflicts with the PKI and DI / TII. Masyumi has a clear political attitude and line towards communism. Regarding the DI / TII rebellion, 
Mohammad Natsir as the leader of Masyumi at that time had a close relationship with the DI / TII figure Kartosuwiryo, but Natsir's efforts to persuade Kartosuwiryo to return to the bosom of the Republic were unsuccessful. In the midst of Masyumi's policies at the central level and conflicts at the local level, Kiai Muchlas used his distinctive philosophy and political strategy in reducing conflict without having to conflict with Masyumi's political attitudes.

\section{Patriotism and the Theory of Political Resistance}

In her study of patriotism, Martens [7] reveals the origins and concepts of patriotism which refer to historical sources from the past of Europe and the United States. According to her, the term "patriotism" comes from the root word pa (Indo-German). From these words, the words pater (Latin) and father, paternal, patriarch, patriotism (English) emerge. From the origin of the word, patriotism is defined as "an attitude of loyalty toward the father" [8]. Some scholars in the past have tried to limit the definition of patriotism. For example, Russell [9] defines patriotism as "a very complex feeling, built up out of primitive instincts and highly intellectual convictions". Meanwhile, Krehbiel [10] defines patriotism as "obligation to the particular group to which one chances to belong, and to its ideals". In its current manifestation, patriotism is an emotion that grows out of living together. Therefore, patriotism is a social emotion. From here, patriotism is defined as "the individual's expression of loyalty to the group [11].

The concept of patriotism comes from the family environment which then extends to tribal organizations, city-states, and nation-states. In the family environment, loyalty and selfsacrifice go to the father. In a tribal organization, one must be loyal and serve the chieftain. Whereas in a city-state, loyalty is aimed at common interests, and in a nation-state, loyalty is aimed at a wider scope, namely the national interest. Referring to the American experience, Professor Robert S. Woodworth in his classic work How War is Changing the Character of the American People (1918), as quoted by Martens (1919: 45-48), argues that self-sacrifice is the basis of all elements of patriotism. Furthermore, he mentioned four elements of patriotism. First, herd instinct or gregarious instinct. This instinct arises because a person feels safe in a flock, and is then willing to sacrifice himself to save the group. Self-interest that rests on the instinct of self-preservation will gradually disappear when a person finds a higher expression to serve his group. Second, the pugnacity of patriotism. This element has its roots in family and tribal organizations. In order to fulfill the needs of the group which had to compete with other groups, one had to be prepared to fight. In this period of conflict, the arrogance of patriotism is normal and necessary to defend the group.

Third, the religious element. The origin of this element is unclear but its character is complex. Many religions teach the importance of combatants in realizing higher ideals. In a monarchical system of government, loyalty to the leader of a national group is considered as devotion to God and is accepted as a sacred duty. Therefore, religious values and patriotic ideas are closely related. Fourth, the love of country. This element is the gradual expansion of patriotism from the family level to a large national organization. The ability of patriotism to expand shows its adaptability in future political developments. The first manifestations of this type of national patriotism were shown during the French Revolution. For the first time, loyalty to state sovereignty was clearly separated from loyalty to group interests. There was pride in the principles and institutions of government and the enthusiasm of the people to protect the common interest grew. 
Ira Woods Howerth (in Martens, 1919: 33) distinguishes between instinctive patriotism and intelligent patriotism. Natural patriotism is a pure, unthinkable reaction. The basis of this natural patriotism emerged from the life history of primitive groups as a quick action to defend the group. Individual action is driven more by feelings without reasoning, so that this character of patriotism is dangerous. The second psychological type of patriotic expression is intelligent patriotism. Different from natural patriotism, intelligent patriotism displays expression in actions that are rational, thoughtful, and therefore constructive. Intelligent patriotism still has an emotional element as a source of motivational power and stimulation to act, but is still under the control of direction and will.

Kleingeld [12], when discussing patriotism based on Kantian moral philosophy [13], distinguishes patriotism into three types: civic patriotism, nationalist patriotism, and traitbased patriotism. Civic patriotism is the spirit of citizens to uphold justice. The main idea is that in the absence of a just legal system, no one can get the right to freedom without resorting to violence against others. Nationalist patriotism is a person's duty to protect his nation, based on the understanding that national affiliation gives meaning and a sense of identity. The basic idea is that nation or nationality is good. Meanwhile, trait-based patriotism is a person's love for the country because they feel that their country is good. This type of patriotism arises on the basis of a person's psychological assessment of the condition of his country, which means that there is a selection of judgments before someone loves their country so that this patriotism is one level above nationalist patriotism.

The history of the rise of nations in Europe shows that patriotism is inseparable from nationalism. Patriotism and nationalism are interrelated concepts. According to Billig [14], nationalism which is associated with rejection of parties outside the group is usually accompanied by patriotism. Russell criticizes patriotism that arises from excessive national pride. Such pride will place patriotism only as a sacrifice within the territory of a country, not for the safety of all mankind. Such national expressions are more destructive than constructive [15]. Russell appears to be on the stronghold of cosmopolitanism in the disagreement between defenders of patriotism and cosmopolitanism. Defenders of cosmopolitanism call patriotism a "dangerous form of parochialism" and that is "very close to jingoism" [16]. Meanwhile, patriotism defenders view cosmopolitanism tends to deny family, community, and country [17].

According to Staub [18], constructive patriotism must be distinguished from blind patriotism. He means that blind patriotism is the intensity of the attitude of the people of a country or group who are not critical in supporting or accepting a policy and practice, and there is no moral consideration of the consequences and influence of policies for other nations or groups. Meanwhile, constructive patriotism balances loyalty for the welfare of one's own group, and an inclusive orientation towards humans, respecting the rights and welfare of all people.

Krehbiel argued that the slogan "My country, right or wrong" contained extreme nationalism. He believed that in order to establish harmony between nations, a new conception of patriotism needed to be created. Quoting Goethe, he said that "above the nations is humanity". Stoddard [19] believed that World War I exposed the mistakes of nationalism that were practiced in Europe. It is generally considered a race war, although not strictly a purebred war. This is because European nations come from three descent, namely the Nordic, Alpino, and Mediterranean descent. These descendants have been mixed up so that World War I was actually a civil war between those who were blood and descendants.

Referring to Billig's opinion that patriotism accompanies nationalism, and nationalism is associated with the rejection of parties outside his group, it can be said that patriotism grows 
out of a spirit of resistance. The question is, is each resistance having a political dimension and an ideological background? What are the characteristics of political resistance? Bilginer [20] tries to answer these questions when examining resistance theory. He studied and compared concepts from the results of the study of Hollander and Einwohner (2004) based on group resistance, Scott (1985) regarding daily peasants' resistance, Arendt (1970) on violence and Arendt (2006a) on civil disobedience, and Laclau \& Mouffe (1985) which modified Karl Marx's radical class struggle into a struggle with a social dimension (from class antagonism to multiple antagonism and from radical political transformation to radical social transformation). Bilginer also considers elements of political ideology in resistance by adopting Freeden's (2003) concept of political ideology.

Bilginer makes the proposition: (1) Despite that political resistance is in continuum with everyday resistance, the former can be distinguished from the latter on the ground that political form of resistance is collective and has to occur in public; (2) Political resistance may or may not employ violent means of opposition; (3) The goal of a genuine and morally defensible resistance is either the liberation from oppression as a prerequisite for the constitution of political freedom (where it is non-existent) or the expansion of political equality (where freedom partially exists); and (4) The theorists of political resistance are left at an empirical impasse due to the fact that there are almost always a number of resisting groups, who come from different ideological backgrounds but employ the same political language of freedom. On the aims and patterns of political resistance: A genuine political resistance strives to penetrate politics to change the rules of the game for the better but without using the conventional political methods. A genuine act of resistance upholds egalitarian claims, such as a fair distribution of resources essential to the development of political freedoms, and the expansion of assigned freedoms to greater numbers of people in a given political community [21].

Political resistance can be divided into: non-violent and legal (street protests, rallies, strikes, walk-outs); non-violent but illegal (illegal sit-ins, occupation of a public building or a park); violent and illegal (tyrannicide, armed resistance, draft-card burning). The concept of political resistance on the basis of two major characteristics: the public character of political resistance (any act of resistance as a practical-critical activity since political action from below takes place in the world of becoming. people and always judged by others); the ideological character of political resistance (to see political ideologies in a positive light since they make the multilayered relations of society intelligible to us and render our engagement in the affairs of society meaningful) [22]. From these propositions and conclusions, it can be noted that the difference in concept between daily resistance and political resistance has melted away. It is no longer debatable whether an act of resistance should be visible or invisible, individual or collective. Political resistance is characterized as an attitude or action of resistance that is collective in nature and occurs in the public sphere, using or not using violence, legal or illegal. The goal is to free oneself from oppression in order to realize political freedom or equality in a common movement with ideological backgrounds that may be different.

\section{The Ideology of Resistance in Islamic Theology}

In order to discuss the patriotism and resistance of the ulama in Indonesia during the colonial period and afterward, it is necessary to trace its historical and theological background. This investigation was intended to identify the ideological roots of the nationalism of the ulama and the anti-colonial spirit that became the driving force for the struggle for Indonesian independence. Historically, as indicated by several studies, the rise of Indonesian nationalism 
was inseparable from the new consciousness brought by the ulama from Mecca and the pilgrims after returning from the Holy Land. Laffan [23], for example, after tracing a network of religious publishing in Southeast Asia since 1900 connected to the "ecumenism of Mecca" in the 19th century and the "national spirit of Cairo" in the 20th century, came to the discovery that Islam played an important role in the formation of nationalism in Indonesia.

Indonesian nationalism developed when Indonesians, as Muslims, found transcendental identification during the pilgrimage in the Holy Land. "Orang Jawi" feel they find the same identity in Islam [24]. This finding differs from Anderson's idea of an "imagined community". Ben Anderson, according to Laffan, did not include notes on "the belief of the majority of the islanders" [25]. Islam, as Laffan pointed out, is the center of the formation of nationalism. He said: "I hope to demonstrate how Muslim reformists, whose activities were focused on the peoples and concerns of the Netherlands Indies, expressed their sense of imagined community above all else as a function of Islam." [26]

Previously, Stoddard [27], showed another spirit in Islam that unites its adherents in the same identity. This spirit is called "Islamic solidarity" which binds all Muslims in the world. He emphasized that there is no other religion that binds its adherents so strongly besides Islam. Islamic solidarity can be seen from the pilgrimage procession and the caliphate institution (during the Ottoman era). Pan-Islamism, in Stoddard's observation, is only a generator of this spirit of solidarity. The political implications of the pilgrimage are much stronger and more entrenched than Pan-Islamism. The Hajj is actually the eternal congress of Pan-Islamism where all religious matters are discussed by delegates from all corners of the Islamic world.

Pan-Islamist figures Jamal al-Din al-Afghani with Muhammad Abduh, Rashid Rida, Hassan al-Banna, al-Kawakibi, and Amir Shakib Arsalan, as well as Islamic intellectuals such as al-Nadhim, al-Tahtawi, Lutfi al-Sayyid, al -Masrafi, Ali Abd al-Razik, and Taha Husayn, have adopted the spirit of European patriotism and nationalism to raise the resistance of Islamic nations. Their goal is the same: to raise the patriotism of Islamic nations against imperialism [28]. Rida emphasized the importance of nationalism and patriotism for the Muslim world because they are relevant to the interests of national independence. According to their view, in principle, Islam is one of the factors of nationalism. The difference is that AlAfghani, Abduh, Rida, and al-Banna, al-Kawakibi, and Shakib Arsalan saw Islam as a political ideology. While al-Nadhim, al-Tahtawi, Lutfi al-Sayyid, al-Masrafi, Ali Abd alRazik, and Taha Husayn put Islam as a moral force [29].

Among the many ideologues and Muslim intellectuals is Hassan al-Banna, the founder of Ikhwan al-Muslimeen (Islamic Brotherhood), who has provides a clearer understanding and details about patriotism in the view of a Muslim. He made a distinction between wataniyya (patriotism) and qawmiyya (nationalism) and between true and false kinds of patriotism and nationalism. Firstly, wataniyya al-banin is the love for one's country and place of residence, driven by both nature and Islam. The Prophet Muhammad and Bilal themselves expressed their love for their hometown of Mecca. Secondly, wataniyya al-hurriyya wa al-izza is the desire for independence and pride in one's own country. Thirdly, wataniyya al-fath is the desire for conquest and world domination. Fourthly, wataniyya al-hizbiyya is the love for party-strife and the bitter hatred of one's political opponents with all its destructive consequences. It is only the latter that is the false kind of wataniyya according to al-Banna [30].

The ideology of resistance which is one of the core theology of Islam which cannot be found in other religions is jihad. Etymologically, the word jihad comes from the word jahada (Arabic) which means "strength", "effort", "painstakingly", or "ability". According to Ibn al- 
Atsir in Al-Nihayah fii Gharib al-Hadith (I / 319), as quoted by Yazid bin Abdul Qadir Jawas [31], in terminology, jihad is defined as "fighting unbelievers; earnestly try; pour out strength and ability in the form of words or deeds. According to Ibn Taymiyya, jihad means devoting all one's abilities to achieve what Allah Azza wa Jalla loves and rejecting everything that Allah hates. This definition covers all categories of jihad that is carried out by a Muslim, which includes his obedience to Allah by carrying out His commands and staying away from His prohibitions. Jihad also means seriousness in inviting (preaching) other people to carry out obedience, whether near or far, Muslims or infidels. Another definition, jihad is serious fighting against unbelievers in order to enforce Allah's sentence [32].

In Islamic theology, jihad fii sabilillah (striving in the path of Allah) is the second main practice after prayer. The reply in the hereafter for those who jihad is heaven (Qur'an, Surah Ash-Shaff: 12) and the reward in the world is in the form of help from Allah and an immediate victory (Surah Ash-Shaff: 13). With God's promise to those who carry out jihad, the commandment of jihad is a great source of motivation for the struggle and resistance of every Muslim. From this, there often comes a different understanding among Muslims themselves who interpret jihad as terror, violence, and war. This interpretation triggers negative perceptions and misunderstandings of the concept of jihad in general. This misconception peaked especially in the Western world after the events of 11 September 2001, which shows that the true meaning of the term jihad is still not well understood by non-Muslims [33].

The ulama say that the law of jihad is fardh 'ain on three conditions [34]. First, when the Islamic armies and the troops of the disbelievers meet and have already faced each other on the battlefield, then no one is allowed to retreat or turn back. Second, if the enemy attacks and surrounds a safe Muslim country, it is obligatory for the inhabitants of that country (except women and children) to come out to fight the enemy (to defend the Motherland). Third, when the leader (imam) asks the people to go to war, they are obliged to leave.

Striving against unbelievers and hypocrites is the order of the Qu'ran (Surah al-Taubah: 73 and al-Tahrim: 9). According to Quraish Shihab [35], against unbelievers, jihad in the form of armed contact was carried out by the Prophet Muhammad, but against hypocrites, the Prophet did not. This gives the impression that jihad against hypocrites is not jihad in the form of taking up arms, because formally they are Muslims, and they also do not openly take action to destroy Islam. Therefore, the maximum effort that can be done to deal with them is to stem the bad influence caused by their attitudes and actions. The Prophet's manifestation of jihad against unbelievers and hypocrites is the main source of law after the Qur'an in Islamic theology, and therefore serves as the moral and ideological guide for every Muslim in applying jihad to changing social and political conditions.

\section{Philosophy and Political Doctrines of K.H. Muchlas}

The spirit of K.H.Muchlas's patriotism was expressed in three periods of his life: the struggle for Indonesian independence, the era of trial democracy or liberal democracy (19501957), and the era of Guided Democracy (1957-1965) [36]. During the independence struggle, the actualization of Kiai Muchlas' patriotism was mainly in the form of spiritual-religious advice and directions to motivate the spirit of struggle for his students, religious scholars and teachers, community leaders, and Muslim youth in Tegal. He conveyed his teachings and spiritual encouragement through recitations at his pesantren as well as in other cities such as Brebes, Pemalang, Pekalongan and Pekajangan, as well as through Friday sermons at the Panggung Mosque. 
K.H. M. Mufid Mas'ud (now the caretaker of the Sunan Pandanaran Islamic Boarding School in Yogyakarta) said that in August 1945, on the days after Indonesia's independence was proclaimed and the national anthem continued to be played, he was invited by a friend from Tegal to visit the Panggung Pesantren. At that time he was still studying at Pesantren Kedawung, Comal, Pemalang Regency, which was raised by K.H. Dimyati, Kiai Muchlas's boarding friend. On the walls of the buildings along the main road from Pemalang to Tegal are plastered various writings, which include the words "merdeka atau mati" (freedom or death). In another place, banners were seen containing the words of "merdeka atau mandi darah" (freedom or bathing in blood), "isykariman auw maut syahidan" (noble life or death syahid), and "kemerdekaan Indonesia harus kita pertahankan dengan harta, jiwa dan raga" (Indonesian independence we must defend with our assets, soul and body) [36]. There were still a number of other writings that he could no longer remember.

Kiai Mufid expressed his memories: "When I saw these writings, I didn't know what their importance was. After I prayed Friday at the Panggung Mosque and, coincidentally, the preacher was K.H. Muchlas, at least I can only grasp the meaning of these writings, because what he delivered in his sermon really moved the hearts of the Muslims in defending the Republic of Indonesia, which basically reminded youths to take war games, with trainers from the government so that can face the Dutch any time they come to the territory of RI. And it turned out to be true what he said at the time of the sermon, not so long ago that the Dutch arrived using their warships on the island of Java and landed in Jakarta, Semarang, Surabaya, with sophisticated war equipment and highly trained troops." [37]

The content of Kiai Muchlas' sermon that he still remembers is a call to the youth to learn (practice) warfare in preparation for facing the Dutch. Meanwhile, to other kiai and his students, Kiai Muchlas invited them to increase their taqarub (approach) to Allah. "The late K.H. Muchlas suggested that people who are still physically strong should defend the country on the battlefield. Meanwhile, the elders (parents) should fast, read the Qur'an, Allah's sayings, and ahzab al-aulia (hizb-hizb compiled by the guardians)," he said. According to Kiai Mufid, at that time the well-known hizb in Indonesia were Hizb al-Nawawi, Hizb Nashri, Hizb alBahri, Hizb Kifayah, and Hizb al-Barri. The understanding that was captured by Kiai Mufid from Kiai Muchlas's message was that the elders read the Qur'an and the Dala'il Khairat book more [38].

Two months after the proclamation of independence, in Tegal there was a movement of the left that wanted to take over the government from the hands of the local Republican rulers. Within only three months, October to December 1945, this movement had expanded to Brebes and Pemalang, so that it became known as the Tiga Daerah incident [39]. The main character of the movement is Kutil (real name Sakhyani), a barber in Talang, about 6 kilometers south of the center of Tegal City. By mobilizing revolutionary youths and lenggaong (village champions), Kutil arrested, detained, and even killed Dutch people, pangreh praja (bureaucrats), and other local rulers who were accused of being accomplices of the Koninklijke Nederlandsch-Indische Leger (KNIL) and Japan. They blockaded the highway at Talang that connects Tegal with Purwokerto.

In this social revolution, two Pesantren Panggung caregivers who were relatives of K.H. Muchlas, namely Kiai Muchidin and Kiai Bisri, was detained by Kutil and threatened with death. Kiai Muchlas, who on November 6, 1945 received a report about this incident from a courier, immediately prepared his students to attack Talang. However, before this plan was carried out, another report came saying that the two kiai had been released by Kutil thanks to Kiai Misbah's help from Slawi. To Kutil, Kiai Misbah put up his body and negotiated so as not to sacrifice the ulama if he did not want to provoke a reaction from the Muslim community. 
Kiai Misbah's challenge was not wrong. The carelessness of Kutil in detaining Kiai Muchidin and Kiai Bisri has touched the authority of Kiai Muchlas, who at that time had become an influential cleric in Tegal with around 800 students studying at his pesantren. Although one of his former students, K.H. Abu Suja'i as a figure of the Indonesian Islamic United Party (PSII) was appointed by Kutil as the regent of Tegal, Kiai Muchlas ignored him. He knew that the appointment of Abu Suja'i was just Kutil's personal decision to embrace religious groups, a pragmatic political strategy that was at the same time antagonistic to the communist ideology itself . However, with his influence as a charismatic cleric and anti-PKI stance, Kiai Muchlas did not use his power to confront the Kutil movement directly. He only survived to protect his family and pesantren community from the influence of communism. For example, when Nur Kaukab, the eldest son of one of his wives (Nyai Faridah), was about to enroll at AAU (Air Force Academy) in Yogyakarta, Kiai Muchlas was worried that Kaukab would become a communist because the army was dependent on who the commander was.

In the period before and after the 1955 Election, when political competition and ideological conflicts increased sharply, while Kiai Muchlas himself and his pesantren continued to experience terror and intimidation from PKI cadres, his political attitude remained "cool". Testimonies from his former students revealed that PKI cadres "spat on the Masyumi signboard" and "occupied the mosque, locked up the grave (in front of the Panggung Mosque), and threatened to chop up Pak Kiai". Facing such terror, Kiai Muchlas only ordered his students to take turns guarding the night at the grave and a number of santri were prohibited from returning to their hometowns because they had to guard the huts during Eid.

Chairman of the Pemuda Masyumi Tegal (Masyumi Tegal Youth), Mohammad Abdul Jalil, said that one day in 1954, Masyumi administrators intended to hold a meeting at a house located south of Texin. The entrance to the house was blocked by PKI people with bicycles lined up as a posse. But, oddly enough, when Kiai Muchlas passed, the PKI masses opened the blockade and invited him to enter the meeting house. As a bodyguard for Masyumi, Abdul Jalil was amazed at the sight. Moreover, Kiai Muchlas also looks calm, he doesn't feel afraid. His astonishment was answered when he later listened to Kiai Muchlas's lecture. Excerpt from his lecture (as Abdul Jalil recalls): "Muslims must be defended as hard as they can, the matter of death is Gusti Allah's business. Muslims should not fight each other. We must fight to defend our country and nation, namely Muslims. Fight for the Gusti Allah, not for money. Hey Masjumi youths, with anyone, maintain a good relationship, you should not attack unless diwiwiti (attacked first)."

Abdul Jalil understood the message of the lecture by saying: "Kiai Muchlas always survived, was never attacked, because he did not want to offend and hurt the PKI." This means that Kiai Muchlas, in his position as chairman of the Majelis Syuro Masyumi Tegal, used a defensive strategy in dealing with party political competition ahead of the 1955 Election. However, if the sentences are understood as a whole, they are interrelated and explain the political ideology that Kiai Muchlas adheres to. Political ideology here is as defined by Freeden as "a set of ideas, beliefs, opinions, and values, which has four main functions in political life": (1) exhibit a recurring pattern; (2) are held by significant groups; (3) compete over providing and controlling plans for public policy; (4) do so with the aim of justifying, contesting or changing the social and political arrangements and processes of a political community. A final function that political ideologies compete over the control of political language.

It is clear that Kiai Muchlas has a very strong belief in God's power, which gives him a source of motivation and orientation in his life. For him, political struggle must be a part of worship to Allah, so that he does not justify people who do politics solely because of money 
(material). As a kiai who is widely known to have mastered Qur'anic interpretation, especially Tafsir Jalalain and Sufism which have become a tradition in pesantren, Kiai Muchlas knows the law and political ethics in Islam. His mastery of Islamic theology gave birth to a clear political doctrine, namely that fellow Muslims must protect each other, not attack each other. Against the PKI masses who were mostly formally Muslim, jihad could not be applied physically, unless they attacked first. As for the infidels who do not fight or do not expel Muslims from their country, a Muslim is not allowed to attack them.

The problem of a Muslim who is at the same time a communist has become a polemic since the emergence of H. Mohammad Misbach from Solo and Tan Malaka, both of whom have close relations with Hendrik Sneevliet, the founder of the Indische SociaalDemocratische Vereenigingor (ISDV). The ambivalence of communist ideology in a Muslim is stated by Tan Malaka in a memoir: "When I stand before God, then I am a Muslim, but when I stand before men, then I am no Muslim, for God has said there are many Satans among men."

In the lead-up to the 1955 elections, all Islamic parties except PSII declared anticommunist. The onslaught against the communists (PKI) was described by Fogg as revealing a number of facts. Among other things, Islamic parties as well as Protestant and Catholic parties considered the PKI a traitor to the nation after the Madiun Rebellion of 1948. The Islamic Union (Persis) in Bandung issued a fatwa against burying the body of a communist and marrying a communist. Masyumi leaders stated that communists were prohibited from living in Indonesia. NU protested against the PKI's plan to attempt to get its name on the ballot as "PKI and those who are non-party aligned." The most radical Masyumi effort to oppose the PKI was the Anti-Communist Front, an organization founded by M. Isa Anshary in Bandung in September 1954. The radical tone of the Anti-Communist Front led to more violent interactions between Muslims and Communists on the ground.

Kiai Muchlas's teaching to always maintain good relations with anyone is a reflection of Islamic morality. In a state of peace, there is no war, this is a common ethic, including in political life. The atmosphere of the 1955 Election campaign placed Masyumi as a "common enemy" for other parties with secular nationalist ideology, particularly the PNI and the PKI. Even with NU (Nahdlatul Ulama), after leaving Masyumi in 1952 and becoming a party on its own, Masyumi had to compete. Masyumi's rivalry with NU was more marked by theological conflicts between modernist Islam and traditionalist Islam. For example, in Kroya, Cilacap, Central Java, a kiai issued a fatwa prohibiting people from voting for Masyumi because they were considered "does not adhere to the jurisprudence school" (talfiq).

The theme of the Masyumi campaign was Islam, in this case modernist Islam, which was used by its political opponents to argue that Masyumi wanted an Islamic state. From this discourse Masyumi was attacked repeatedly by his political opponents. Because of this, Kiai Muchlas's teaching is to always maintain good relations with anyone, in addition to being intended to promote Islamic morals as well as a political strategy to attract sympathy from the masses at the grassroots level, at least to reduce antipathy and attacks from political opponents. As Fogg said, the fierce political competition at the grassroots level finally had to be resolved by the local ulama with their respective doctrines and fatwas. This means that the ulama act as an inspiration for local wisdom.

Abdul Jalil's other testimony that "Masyumi people like Kiai Muchlas are not afraid of death" in the context of the struggle for independence or political competition, none other than shows the characteristics of their patriotism which was built from their philosophy and struggle ideals. The philosophy of the struggle of the Masyumi people is reflected in the words of Kiai Muchlas: "fight for the sake of Gusti Allah" which shows the orientation or purpose of 
the struggle, "Muslims must be defended with all their might" as a commitment to struggle, and "maintain a good relationship, do not attack unless diwiwiti" as a strategy and ethics of struggle.

The philosophy and political doctrine of Kiai Muchlas during the DI / TII rebellion was no different from when he faced the PKI, but his political attitude tended to be super defensive. This is because the family and some of its students have become victims of suspicion and misunderstanding by the security forces. Kiai Muchlas himself was not free from terror and political pressure that threatened his life. He once wanted to be kidnapped by someone. In the early hours of 1953, a man wearing a black headgear and carrying a goblet entered the kitchen of the house. The presence of this stranger surprised one of Kiai Muchlas's wives, Nyai Khodijah, who was about to enter the bathroom. Hearing Nyai Khodijah's scream, the man who was dressed as "Ninja" ran away.

In 1957, Kiai Muchlas and a student, Khulaimi, were interrogated at the Kodim (District Military Command). The interrogators suspected that the Panggung Pesantren was a shelter for DI people. It was a precarious era, there was an SOB (curfew), the students had to have a certificate from their home village, and the children of the GPII (Indonesian Islamic Youth Movement) were being chased by the authorities. GPII children were targeted by the authorities as a result of the Cikini Incident. Three students from the Pesantren Panggung who were GPII activists, namely Sholehul Hadi (son of Kiai Muchlas), Abu Saeri, and Fadhil were arrested and detained in Slawi for several months, then transferred to Nusakambangan. They were only released after Kiai Muchlas fought for their release by asking for help from his friend, H. Muslich, a Hizbullah figure and an official at the Ministry of Religion in Jakarta.

The Cikini incident took place on Saturday evening, 30 November 1957. President Sukarno attended a charity night celebrating the 15th anniversary of the Tjikini College People's School. He was present as a parent of students from Guntur Sukarnoputra and Megawati Sukarnoputri. When Soekarno was being escorted to the car, suddenly a grenade exploded. Soekarno survived but ten people died including the President's bodyguard, children and pregnant women, and 48 others were injured. The perpetrators were Jusuf Ismail, Sa'adon bin Mohamad, Tasrif bin Hoesain, and Mohamad Tasim bin Abubakar who were said to be closely related to DI / TII led by SM Kartosuwiryo. They come from Bima, West Nusa Tenggara. Jusuf and Tasrif are members of the GPII, the Masyumi support organization. The four young men joined the Anti-Communist Movement (GAK) led by Colonel Zulkifli Lubis, a former Deputy Chief of Staff of the Army and an intelligence figure nicknamed "Father of Indonesian Intelligence".

Apart from his son (Sholihul Hadi) being detained in Nusakambangan and tortured until his ears were deaf, his hut was suspected, and some of his students were detained, Kiai Muchlas's wives were also detained at the Koramil Bumiayu (Sub-District Military Command of Bumiayu), Brebes Regency. Nyai Aisyah, Nyai Khodijah, and Nyai Tursinah who were looking for financial assistance at Bumiayu forgot to bring their ID cards, so they were suspected by the Koramil and arrested. Kiai Muchlas asked the West Tegal Sub-District Military Commander Lieutenant Colonel Mudatsir to dispatch and escort them back to Tegal. The DI / TII rebellion put Kiai Muchlas in a difficult position, hampering his movement and political initiatives. There are several reasons that made his struggle and patriotism less developed during the DI / TII conflict. First, the results of the 1955 Election increased the political power of the PKI and lowered the confidence of the Islamic parties. Second, the Cikini Incident involving GPII activists and DI / TII elements, plus the PRRI / Permesta Rebellion, further cornered Masyumi's position and weakened the opposition force. This condition gave President Soekarno who was supported by the PKI a repressive and 
authoritarian attitude [66]. Third, political turmoil during the DI / TII rebellion resulted in social disintegration which reduced the fighting power of the Muslim community.

\section{Conclusion}

The period of struggle for independence and the physical revolution was marked by the movement of nationalities with one common goal: Indonesian independence. The political forces united against the colonialists despite their different ideologies. Islam which played a role in the Indonesian national movement through the influence of Mecca and Cairo was implemented by ulama and nationalists by raising a spirit of patriotism and resistance to the colonialists. Entering the era of Guided Democracy, different ideologies that originally merged in the spirit of the same nationality, are now fighting each other. Political competition and ideological conflicts divide the nation. After successfully repelling the invaders, the Indonesian nation actually fought itself to fight for influence, domination and power.

This political development turned out to determine the changes in the style of patriotism and the characteristics of the Indonesian nation's resistance. In the era of the struggle for independence and physical revolution, national patriotism was constructive and expansive by suppressing personal and group interests. This nationalist patriotism gave rise to civil mobilization as the main force against the colonialists. Hizbullah as an Islamic militia formed by Masyumi merged into the national resistance with the support of spiritual and supernatural powers from the ulama. The blessing of bambu runcing (pointed bamboo) by Kiai Subeki in Parakan, Kiai Muchlas in Tegal, and Kiai Noer Alie in Bekasi closed the weaknesses of the traditional weapons of the Hizbullah army in Java in the face of Dutch military aggression. The spirit of patriotism to seize independence and political freedom, or wataniyya al-hurriyya wa al-izza in the concept of Hassan al-Banna, is strengthened by religious values. The ulama strengthened the political ideology of resistance by adding moral strength.

It was in that patriotic era that K.H. Muchlas demonstrated his political philosophy and doctrine to mobilize resistance against the invaders and direct the attitude of the Masyumi masses towards political opponents. He used the doctrine of jihad in encouraging young men to train in warfare and enter the battlefield. But when facing PKI, he used a humanist Islamic political ideology to develop intelligent patriotism or what could be called "guided patriotism". This patriotism contradicts the anti-PKI spirit at the national level and Masyumi's attitude, but Kiai Muchlas, who knows the conditions on the ground, wants to avoid physical violence. These political philosophies and doctrines sank in the Guided Democracy era because the local political situation was beyond his control. Ideological conflict and coercion at the level much louder than in the center. In this situation what is more needed is political resistance, not patriotism, to demand justice and freedom. Unfortunately, political resistance did not develop because collectivity was defeated by authoritarianism.

\section{References}

[1] Abdullah, Taufik. (1981). Manusia dalam Kemelut Sejarah. Jakarta: LP3ES.

[2] Achmad. (1987). Ungkapan Peristiwa Tiga Daerah: Tegal - Brebes - Pemalang. Tegal: Markas Cabang Legiun Veteran RI Kabupaten/Kota Tegal 
[3] Ali, Muhammad. (2014). "Nationalism and Islam: Perspective of Egyptian and Syrian Muslim Intellectuals", IJIMS, Indonesian Journal of Islam and Muslim Societies, Volume 4, Number 1, June.

[4] Arklay, Tracey. (2006). "Political Biography: It's Contribution to Political Science". In Tracey, et, all, eds, Australian Political Lives: Chronicling Political Careers and Administrative Histories. Canberra: ANU E Press.

[5] Baso, Ahmad. (2016). Kyai Subchi Bambu Runcing, https://www.dutaislam.com/2015/12/kyai-subchi-bambu-runcing.html, 01 Januari.

[6] Bilginer, Onur. (2015). Theories of Political Resistance: The Making of Resistance from the Sixteenth Century to the Present. Ph.D. Dissertation. Rockefeller College of Public Affairs \& Policy Department of Political Science University at Albany. New York: State University of New York.

[7] Billig, M. (1995). Banal Nationalism. London: SAGE Publications.

[8] "Chauvinism", https://www.merriam-webster.com/dictionary/chauvinism.

[9] Dahlan, Moh. (2009). "Pemikiran Filsafat Moral Immanuel Kant (Deontologi, Imperatif Kategoris dan Postulat Rasio Praktis)", Ilmu Ushuluddin, Vol.8, No.1, Januari.

[10] Fogg, Kevin William. (2012). The Fate of Muslim Nationalism in Independent Indonesia, Ph.D Dissertation. Yale University.

[11] Freeden, Michael. (2003). Ideology: A Very Short Introduction. Oxford: Oxford University Press.

[12] Isnaeni, Hendri F. (2019). CIA dalam Peristiwa Cikini, https://historia.id/militer/articles/cia-dalam-peristiwa-cikini-vqmky/page/3, 7 September.

[13] Jawas, Yazid bin Abdul Qadir. (2012). "Jihad, Amalan yang Paling Utama", AsSunnah, Edisi 12/Tahun XV/1433 H.

[14] "Jingoism", https://www.merriam-webster.com/dictionary/jingoism.

[15] Kleingeld, Pauline. (2000). "Kantian Patriotism", Philosophy and Public Affairs, 29, 4.

[16] Knapp, Michael G. (2003). "The Concept and Practice of Jihad in Islam", Parameters, Spring 33,1 .

[17] Krehbiel, Edward. (1916). Nationalism, War and Society. New York: The Macmillan Co.

[18] Laffan, Michael Francis. (2003). Islamic Nationhood and Colonial Indonesia: The Umma Below the Winds. London: Routledge, Curzon.

[19] Lev, Daniel S. (2009). The Transition to Guided Democracy: Indonesian Politics, 1957-1959. Singapore: Equinox Publishing.

[20] Lucas, Anton E. (2004). One Soul One Struggle: Peristiwa Tiga Daerah. Yogyakarta: Resist Book.

[21] Mackie, J.A.C. (1961). "Indonesian Politics under Guided Democracy". Australian Outlook, 15:3. DOI: 10.1080/00049916108565403.

[22] Madjid, M. Dien \& Johan Wahyudhi. (2014). Ilmu Sejarah: Sebuah Pengantar. Jakarta: Prenada Media Group.

[23] Martens, Frieda. (1919). A Sociological Analysis of Patriotism. M.A. Thesis. California: Department of Sociology, University of Southern California.

[24] "Mengenal Tafsir Jalalain", https://rumaysho.com/23416-mengenal-tafsir-jalalain.html.

[25] Mitchell, Richard P. (1968). The Society of the Muslim Brothers, Oxford: Oxford University Press. 
[26] Nizar, M. Coirun dan Muhammad Aziz. (2015). "Kontekstualisasi Jihad: Perspektif Keindonesiaan", Ulul Albab, Volume 16, No.1.

[27] Ricklefs, M.C. (2007). A History of Modern Indonesia Since c. 1200 Third Edition (Sejarah Indonesia Modern 1200-2004), tr. Satrio Wahono et all. Jakarta: P.T. Serambi Ilmu Semesta.

[28] Rieffer, Barbara-Ann J. (2003). "Religion and Nationalism: Understanding the Consequences of A Complex Relationship", Ethnicities, Vol 3(2).

[29] Russell, Bertrand. (1917). Why Men Fight. New York: The Century Co.

[30] Samsuri. (2001). "Komunisme dalam Pergumulan Wacana Ideologi Masyumi", Millah, Vol. 1, No. 1, Agustus.

[31] Schwartz, Stephen Suleyman. (2009). Islam and Communism in the 20th Century: An Historical Survey. Washington DC \& London: The Center for Islamic Pluralism.

[32] Shihab, M. Quraish et.all. (2007), Ensiklopedia al-Quran: Kajian Kosakata. Jakarta: Lentera Hati.

[33] Staub, E. (1997). "Blind Versus Constructive Patriotism: Moving from Embeddedness in the Group to Critical Loyalty and Action". In D. Bar-Tal \& E. Staub (Eds.), Patriotism: In the Lives of Individuals and Nations. Chicago: Nelson-Hall.

[34] Stoddard, Lothrop. (1966). Dunia Baru Islam (The New World of Islam). Terj. Panitia Penerbit. Jakarta: Panitia Penerbit.

[35] Sulistyo, Hermawan. (2001). Palu Arit di Ladang Tebu: Sejarah Pembantaian Massal yang Terlupakan (Jombang-Kediri 1965-1966). Jakarta: Kepustakaan Populer Gramedia.

[36] "Timbangan Buku”. (1968). Al-Djami'ah No. 4 Th. 7. Retrieved from http://digilib.uin-suka.ac.id/28079/2/Anonim\%20-\%20Resensi\%20\%20Dunia\%20Baru\%20Islam.pdf.

[37] Utami, C. Santi Muji. (2019). "Traditional Industries in the Colonial Period: The Economic Activities of the People of Tegal in the First Half of the 20th Century". Paramita: Historical Studies Journal, 29 (1).

[38] Zuhri, Saifuddin. (1987). Berangkat dari Pesantren. Jakarta: Gunung Agung.

[39] M. Mufid Mas'ud, K.H (Pesantren Sunan Pandanaran Yogyakarta) 